\title{
Merkel Cell
}

National Cancer Institute

\section{Source}

National Cancer Institute. Merkel Cell. NCI Thesaurus. Code C12592.

An epidermal cell, primarily located in the basal layer, that is thought to function in tactile sensory perception. 